\title{
EFFECTS OF LEVELS OF NITROGEN AND POTASSIUM ON YIELD AND FRUIT MATURATION OF IRRIGATED GUAVA TREES IN THE SÃO FRANCISCO VALLEY ${ }^{1}$
}

\author{
MARIAAUXILIADORA COÊLHO DE LIMA², LUÍS HENRIQUE BASSOI², DAVI JOSÉ SILVA², POLYANE DE SÁ SANTOS ${ }^{3}$, \\ PRISSILA DE CASTRO PAES ${ }^{3}$, PAULA ROSE DE ALMEIDA RIBEIRO ${ }^{3}$, BÁRBARAFRANÇA DANTAS ${ }^{2}$
}

ABSTRACT - Yield and physical and chemical characteristics of 'Paluma' guava fruit were evaluated as a function of the harvest at different maturity stages, under influence of nitrogen and potassium fertilization, in Petrolina, State of Pernambuco, Brazil. Fertilizer rates were $67 \mathrm{~kg} \mathrm{~N}+33 \mathrm{~kg} \mathrm{~K} 20,133 \mathrm{~kg} \mathrm{~N}+67 \mathrm{~kg} \mathrm{~K} 2,200 \mathrm{~kg} \mathrm{~N}+100 \mathrm{~kg} \mathrm{~K} \mathrm{O}_{2}$ and $267 \mathrm{~kg} \mathrm{~N}+133 \mathrm{~kg} \mathrm{~K} \mathrm{O}_{2}$ per hectare. Fruits were evaluated at maturity stages 2, 3, 4 and 5, established according to peel color. Higher doses of $\mathrm{N}$ and $\mathrm{K}$ induced higher yields. Nevertheless, fertilization with $200 \mathrm{~kg}$ of $\mathrm{N}+100 \mathrm{~kg}$ of $\mathrm{K}$ per hectare improved fruit quality, delaying ascorbic acid breakdown and conserving pulp firmness. Main changes took place at maturity stages 4 and 5 , when the fruit should present ideal conditions for consumption, namely the increase on soluble solids and soluble sugars content.

Index terms: Psidium guajava L., nutrition, maturity stages, fruit quality.

\section{EFEITOS DOS NÍVEIS DE NITROGÊNIO E POTÁSSIO NA PRODUTIVIDADE E NA MATURAÇÃO DOS FRUTOS DE GOIABEIRA IRRIGADA NO VALE DO SÃO FRANCISCO}

RESUMO - O presente trabalho avaliou a produtividade e as características físicas e químicas dos frutos de goiabeira 'Paluma' em diferentes estádios de maturação, sob a influência de adubações nitrogenada e potássica, em Petrolina-PE. As plantas foram submetidas à aplicação de $67 \mathrm{~kg} \mathrm{~N}+33 \mathrm{~kg} \mathrm{~K} 2 \mathrm{O}, 133 \mathrm{~kg} \mathrm{~N}+67 \mathrm{~kg} \mathrm{~K} \mathrm{O}_{2}, 200 \mathrm{~kg} \mathrm{~N}+100 \mathrm{~kg} \mathrm{~K} 2 \mathrm{O}$ and $267 \mathrm{~kg} \mathrm{~N}+133 \mathrm{~kg} \mathrm{~K} \mathrm{O}_{2}$ por hectare, sendo os frutos avaliados nos estádios de maturação 2; 3; 4 e 5, caracterizados conforme a cor da casca. As maiores doses de $\mathrm{N}$ e $\mathrm{K}$ resultaram em maiores produtividades, mas as aplicações de $200 \mathrm{~kg}$ de N $+100 \mathrm{~kg}$ de $\mathrm{K}$ por hectare favoreceram a qualidade do fruto, resultando em menor degradação de ácido ascórbico e preservação da firmeza da polpa. As principais mudanças que ocorreram entre os estádios 4 e 5, quando o fruto apresentaria condições ideais para consumo, foram relativas ao acúmulo de sólidos solúveis e de açúcares solúveis.

Termos para indexação: Psidium guajava L., nutrição, estádios de maturação, qualidade do fruto.

\section{INTRODUCTION}

In the São Francisco Valley, guava crop has been characterized by its socioeconomic aspects and as a component of the regional agribusiness. Northeast Brazil is the largest guava producer with approximately 9,000 ha, which corresponds to $52 \%$ of total guava area in Brazil, and a production of 155,000 t. Around $71 \%$ of it comes from the State of Pernambuco (IBGE, 2005).

Nevertheless, guava growers from this region have not improved neither the cropping systems nor adopted post harvest practices which would allow them to trade with external markets. Hence, the production has been sold within the regional markets (Northeast Brazil) and the possibility of a higher profit has not been achieved.

As in any other guava growing area in the world, trading with external markets is considered very difficult because of the fruit perishability, due to inadequate handling practices and deficient transport and storage infrastructure (Bashir \& AbuGoukh, 2003).

In the São Francisco Valley, 'Paluma' is the most extensively grown cultivar as it presents a good adaptation to local soil and weather conditions. As compared to other cultivars, 'Paluma' it is characterized by its firmness, good flavor and post harvest conservation (Pereira, 1983).

The relatively high consumption of guava is a consequence of its nutritional values and to the several opportunities of using as fresh or processed. Guava is one of the most complete tropical fruits, with high vitamin $\mathrm{C}$ level, as earlier reported by Malavolta \& Soybihe Sobrinho (1951), reasonable mineral salt contents ( $\mathrm{Ca}, \mathrm{Se}, \mathrm{Cu}, \mathrm{P}, \mathrm{Mg}, \mathrm{Fe}$ ), folic acid, vitamin $\mathrm{A}$ and $\mathrm{B}$ complex vitamins. It is also rich in $\mathrm{Zn}$, fiber, niacin, lycopene, and vitamin E (Choudhury et al., 2001). Nevertheless, these characteristics are dependent upon cropping conditions and others such as variety, mineral nutrition, maturity stage, and

'(Trabalho 031-07). Recebido em :26-01-2007. Aceito para publicação em: 19-07-2007. Research work financially supported by Banco do Nordeste do Brasil, FACEPE and CNPq.

${ }^{2}$ Researcher, Embrapa Tropical Semi-Arid, P.O. Box 23, 56302-970, Petrolina - PE, Brazil. E-mail: maclima@cpatsa.embrapa.br, 1hbassoi@cpatsa.embrapa.br, davi@cpatsa.embrapa.br, barbara@cpatsa.embrapa.br

${ }^{3}$ Undergaduation student on Biology, CNPq/PIBIC fellow, Universidade de Pernambuco (UPE), Faculdade de Formação de Professores de Petrolina (FFPP), BR 203, Km 02, 56300-000, Petrolina-PE, Brazil. polyanesantos@ig.com.br, prissilacastro@yahoo.com.br, paula@cpatsa.embrapa.br 
weather conditions during the fruit development (Cardoso et al., 2002).

Research on improvement of the cropping practices, as mineral nutrition, associated to appropriated harvesting time, can produce different results with regard to fruit quality and better post harvest conservation. Beside that, more attention to the cultivar particularities can explain specific responses of guava in a certain region. The extrapolation is not valid from one region to another, which means the need of local research for a more complete knowledge of factors influencing fruit quality (Esteves \& Carvalho, 1982).

Studies on the effect of fertilizer rate on fruit quality are able to give the information about the role nutrients play on the synthesis of specific components in the fruit maturation. A higher $\mathrm{N}$ and K requirements have been reported (Natale, 1993; Gonzaga Neto et al., 1998). $\mathrm{N}$ is part of amino acids, proteins and nucleic acids, and plays a role in important processes as ionic absorption, photosynthesis, respiration, cell division and differentiation (Malavolta et al., 1989). K acts in the cell turgor mechanism, carbohydrate transportation, and fruit quality (Marschner, 1995). Consequently, while $\mathrm{N}$ is fundamental for plant structure, facilitating growth and yield, $\mathrm{K}$ promotes, by transportation of assimilates, an increase of fruit weight, flavor, taste, and storability.

The purpose of this study was to evaluate the yield and the physical and chemical changes on maturity stages of guava fruit, in response to levels of $\mathrm{N}$ and $\mathrm{K}$ fertilizer applied through irrigation water.

\section{MATERIAL AND METHODS}

A field experiment was carried out at Bebedouro Experimental Field, Embrapa Tropical Semi-arid, in Petrolina, State of Pernambuco, Brazil, (09 09' S, $40^{\circ} 22^{\prime} \mathrm{W}$ and $\left.365.5 \mathrm{~m}\right)$ where guava trees cv. 'Paluma' were planted in a 5 x 6 m grid spacing on May 2003, in a Yellow Red Latosoil, medium texture.

The beginning of the growing season was August $30^{\text {th }}$, 2004 (pruning date), sixteen months after planting. Plants were irrigated by micro sprinklers and fertilizers were applied weekly through the irrigation system until phenological phase of fruit growth. Irrigation scheduling was set according to reference evapotranspiration as estimated by the Penmam-Monteith method (Allen et al., 1998). Guava crop coefficient estimated for local conditions was used (Ferreira, 2004).

Four N and $\mathrm{K}$ levels were tested: $1-67 \mathrm{~kg} \mathrm{~N}+33 \mathrm{~kg} \mathrm{~K} \mathrm{O}$; 2- $133 \mathrm{~kg} \mathrm{~N}+67 \mathrm{~kg} \mathrm{~K}_{2} \mathrm{O} ; 3-200 \mathrm{~kg} \mathrm{~N}+100 \mathrm{~kg} \mathrm{~K}_{2} \mathrm{O}$; and $4-267 \mathrm{~kg}$ $\mathrm{N}+133 \mathrm{~kg} \mathrm{~K} \mathrm{O}$ per hectare. $\mathrm{N}$ and $\mathrm{K}$ sources were urea and potassium chloride, respectively. Data for production $\left(\mathrm{g} \mathrm{plant}^{-1}\right)$ and fruit number were recorded from three plants per plot and yield $\left(\mathrm{t} \mathrm{ha}^{-1}\right)$ was estimated. The experimental design was randomized blocks, with four treatments ( $\mathrm{N}$ and $\mathrm{K}_{2} \mathrm{O}$ levels) and five replications. The data were submitted to analysis of variance and polynomial regression.

Fruit maturation was analyzed at four maturity stages: 2 (light green), 3 (yellowish green), 4 (mate) and 5 (yellow). Fruit harvests in these stages have occurred on Feb $21^{\text {st }}$, Feb $28^{\text {th }}$, Mar $7^{\text {th }}$, and Mar $9^{\text {th }}, 2005$, which correspond to $175,182,189$, and 191 days after pruning, respectively. The experimental lay out was a randomized blocks, with a $4 \times 4$ factorial $\left(\mathrm{N}\right.$ and $\mathrm{K}_{2} \mathrm{O}$ levels $\mathrm{x}$ maturity stages) design, with four replications. At each maturity stage, four fruits were sampled from two plants per plot. The variables were fresh fruit weight $(\mathrm{g})$; pulp firmness $(\mathrm{N})$, obtained by a handle penetrometer equipped with a $8 \mathrm{~mm}$ diameter tip; total titratable acidity (TTA, \% of citric acid), determined by titulation with $\mathrm{NaOH} 0,1 \mathrm{~N}$ (AOAC, 1992); total soluble solids (TSS, ${ }^{\circ}$ Brix) obtained by a temperature self compensating digital refratometer (AOAC, 1992); ascorbic acid content (AA, mg 100 ${ }^{-1}$ ) (AOAC, 1992); and soluble sugars (SS, g 100 $\mathrm{g}^{-1}$ ), as described by Yemn \& Willis (1954). The pulp firmness was evaluated at the maturity stage 3 as a consequence of the device's upper limit used $(129 \mathrm{~N})$ being lower than the pulp firmness on maturity stage 2. ANOVA and Tukey test $(\mathrm{P}<0.05)$ were used to compare the averages.

\section{RESULTS AND DISCUSSION}

Higher $\mathrm{N}$ and $\mathrm{K}_{2} \mathrm{O}$ levels led to higher production per tree, estimated yield and number of fruits (Figure 1a, b, c, respectively).

Fresh fruit weight increased following the maturity stages: from $150.8 \mathrm{~g}$ in stage 2, to $202.6 \mathrm{~g}$ in stage 5, according to the average values for the $\mathrm{N}+\mathrm{K}_{2} \mathrm{O}$ levels (Table 1). This response is on agreement with Cardoso et al. (2002), who has analyzed the same variety in the Curu Valley, State of Ceará, Northeast Brazil. As the fruit sizes varied from medium to large, they should be well accepted by the market which demands a minimum weight of $100 \mathrm{~g}$ for in natura consumption (Lima et al., 1999). Nevertheless, other quality characteristics, as appearance and nutritional values, should be taken into account

The fresh fruit weight was not influenced by the rates of either $\mathrm{N}$ or $\mathrm{K}_{2} \mathrm{O}$. Although the effect of $\mathrm{Ca}$ on fruit characteristics was not addressed in this study, it is interesting to report that Prado et al. (2005) did not observe the influence of different $\mathrm{Ca}$ rates (lime as a source) in the main physical characteristics of 'Paluma' guava fruit.

The pulp firmness has decreased from the maturity stage 3 (when it began to be analyzed) to the next stage. It did not differ, however, from the maturity stage 5 (Table 1), when it had a value of $15.95 \mathrm{~N}$. Bashir \& Abu-Goukh (2003) reported an eightfold decrease of pulp firmness, from the physiological maturity, when they were harvested they still with the green peel, before full ripening. According to Tucker (1993), the firmness loss during maturation is due, in general, to an intensive solubilization of pectin from the cell wall, to starch breakdown and reduction of turgor.

Softening in the pulp and fruit yellowing were associated to other factors besides the pectin solubilization. The reduction of protein content and the increase in water content are also related to this process (El-Buluk et al., 1995).

The combination of $\mathrm{N}$ and $\mathrm{K}_{2} \mathrm{O}$ levels influenced also the fruit firmness (Table 2). Throughout all maturity stages, firmest fruits were those from the levels of either $67 \mathrm{~kg} \mathrm{~N}+33 \mathrm{~kg} \mathrm{~K}_{2} \mathrm{O}$ or 
$133 \mathrm{~kg} \mathrm{~N}+67 \mathrm{~kg} \mathrm{~K} \mathrm{O}_{2}$ per hectare. Consequently, it suggests that the role for $\mathrm{K}$ in the maintenance of cell turgescence, which contributes to the tissue resistance, is not maintained when it is associated to high $\mathrm{N}$ rates. Actually, $200 \mathrm{~kg}$ of $\mathrm{N}+100 \mathrm{~kg} \mathrm{~K} 2 \mathrm{O}$ per hectare did not differ from the two other rates mentioned previously.

The TSS content did not change at stages 2,3 , and 4, approximately $9.5^{\circ}$ Brix, and increased to $11.0^{\circ}$ only at stage 5, under the average values of the $\mathrm{N}+\mathrm{K}_{2} \mathrm{O}$ levels (Table 1). This stability in the early maturity stages was already observed in other studies with different guava varieties, and suggests a typical characteristic that can be directly related to factors of sugar synthesis from starch breakdown accumulated during fruit growth. Bashir \& Abu-Goukh (2003) reported that the change, which leads the fruit to soften, sweetens, and to be less acid with lower astringency and flavorful were coincident with the respiratory peak, which characterizes guava as climacteric. During the 'Paluma' guava fruit maturation, the increase of TSS content observed in the late stage confirms the statement of MercadoSilva et al. (1998), that TSS content is not a good harvest index.

The SS accumulation was similar to the TSS (Table 1). The SS content for the $\mathrm{N}+\mathrm{K}_{2} \mathrm{O}$ levels was approximately $6.8 \mathrm{~g}$ $100 \mathrm{~g}^{-1}$ until stage 4 . In the later maturity stage, $\mathrm{SS}$ content reached


fruits of 'Paluma' guava. Different results were obtained by Cardoso et al. (2002) in State of Ceará, Brazil. Bashir \& AbuGoukh (2003) found that only after the climacteric peak, an evident increase of SS content takes place. This response can be attributed either to the increase in activity of enzymes responsible for starch breakdown, or reduction of rate of respiratory process. The combination of $\mathrm{N}$ and $\mathrm{K}_{2} \mathrm{O}$ levels has influenced the SS contents, and the $200 \mathrm{~kg} \mathrm{~N}+100 \mathrm{~kg} \mathrm{~K}_{2} \mathrm{O}$ and $67 \mathrm{~kg} \mathrm{~N}+33 \mathrm{~kg} \mathrm{~K}_{2} \mathrm{O}$ per hectare were the most favorable (Table 2).

TTA decreased for the $\mathrm{N}$ and $\mathrm{K}_{2} \mathrm{O}$ levels from 0.85 to $0.49 \%$ as maturation takes place from stage 2 to 5 (Table 1). Similar results were found by Cavalini (2004). Nevertheless, during the fruit maturation of some guava varieties, an initial TTA increase is observed until the climacteric peak, when then it decreases (Bashir \& Abu-Goukh, 2003). The highest TTA value was registered at stages 2 and 3 , as expected on fruits in the beginning of maturation process. At stages 4 and 5, significant differences were not observed.

Organic acids represent one of the main substrates in the respiratory process during ripening, and this explains the tendency of significant reduction of these compounds at this stage (Tucker, 1993).

In a general way, it was observed the reduction of AA content during fruit maturation, the values being influenced by $\mathrm{N}$ and $\mathrm{K}_{2} \mathrm{O}$ levels (Figure 2). With the advance of ripening, the oxidation of acids, including that ascorbic acid, causes the reduction of $\mathrm{C}$ content of these compounds in the pulp (Tucker, 1993). The reduction of AA content during guava fruit maturation was already recorded (Bashir \& Abu-Goukh, 2003), despite the small differences between the contents from the fruits evaluated in the physiological maturity and in the ripe stage. Herein, however, they were remarkable.
Besides that, Cavalini (2004) observed an increase in the content of AA at the late maturity stage. Despite being a distinct response from that obtained in this study, the values recorded by that author were similar to those presented in Figure 2.

The application of $200 \mathrm{~kg} \mathrm{~N}+100 \mathrm{~kg} \mathrm{~K}_{2} \mathrm{O}$ per hectare seemed to be associated with a slow degradation of ascorbic acid, because there were no differences on contents between stages 2 and 3, and between stages 4 and 5 (Figure 2). This response suggests that fruits harvested in stages 3 and 4 have different attributes of quality as a consequence of AA content as compared to the other N and K rates. Ali \& Lazan (1997) reported that certain combinations of $\mathrm{N}$ and $\mathrm{K}$, as well as of $\mathrm{B}$, $\mathrm{Mg}$, and $\mathrm{Zn}$, can influence the AA content in the ripe fruit.

It is important to notice that knowledge of changes in fruit composition as function of the cropping practices allows for the understanding of the metabolic processes related to the ripening, such as pulp softening and senescence. Finally, it is possible to propose market practices and post harvest standards that are suitable for fruit quality obtained under certain growing conditions (Bashir \& Abu-Goukh, 2003).
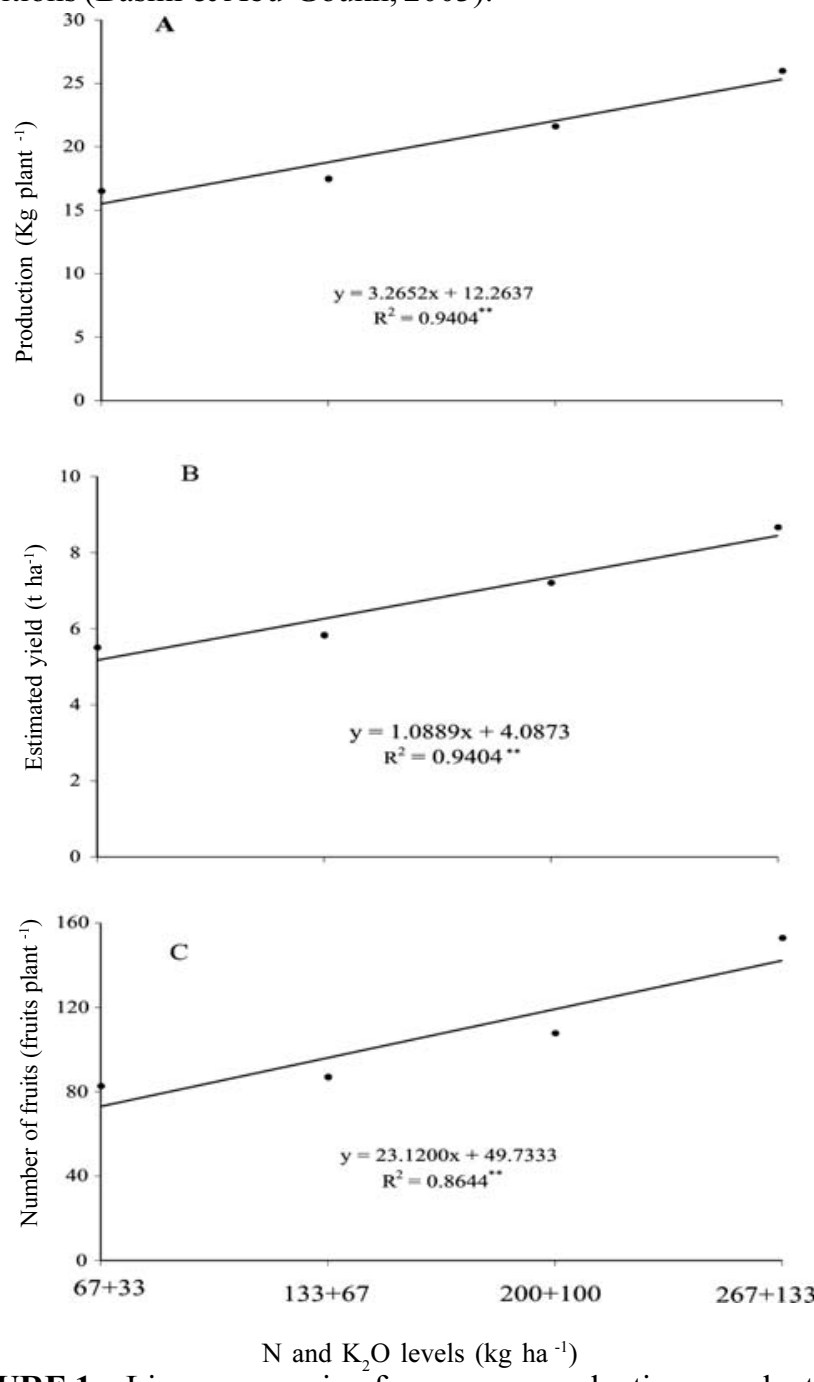

FIGURE 1 - Linear regression for average production per plant (A), estimated yield (B) and number of fruits (C) of guava trees, fertigated with different levels of $\mathrm{N}$ and $\mathrm{K}_{2} \mathrm{O}$. 


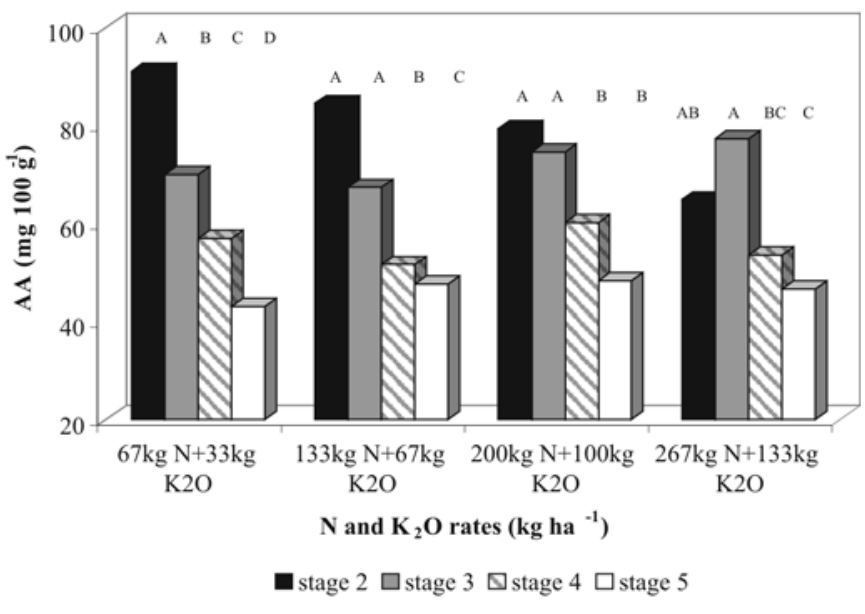

FIGURE 2 - Ascorbic acid content (AA) in 'Paluma' guava fruit as function of different $\mathrm{N}$ and $\mathrm{K}_{2} \mathrm{O}$ levels and of maturity stages. Values followed by the same letter in the columns of the same $\mathrm{N}$ and $\mathrm{K}_{2} \mathrm{O}$ levels did not differ by Tukey test $(\mathrm{P}<0.05)$.

TABLE 1. Fresh fruit weight, pulp firmness, total soluble solids content (TSS), soluble sugars content (SS), and total titratable acidity (TTA) of 'Paluma' guava fruit in different maturity stages. Average values of $\mathrm{N}$ and $\mathrm{K}_{2} \mathrm{O}$ levels."

\begin{tabular}{cccccc}
\hline Maturity stage & Fresh weight $(\mathrm{g})$ & Pulp firmness $(\mathrm{N})$ & TSS ( ${ }^{\circ}$ Brix $)$ & SS $\left(\mathrm{g} .100 \mathrm{~g}^{-1}\right)$ & TTA $(\%$ citric a cid $)$ \\
\hline 2 & $150.88 \mathrm{a}$ & - & $9.5 \mathrm{a}$ & $6.46 \mathrm{a}$ & $0,86 \mathrm{a}$ \\
3 & $170.74 \mathrm{ab}$ & $38.35 \mathrm{a}$ & $9.5 \mathrm{a}$ & $6.55 \mathrm{a}$ & $0.66 \mathrm{~b}$ \\
4 & $183.65 \mathrm{bc}$ & $18.70 \mathrm{~b}$ & $9.7 \mathrm{a}$ & $7.34 \mathrm{a}$ & $0.56 \mathrm{c}$ \\
5 & $202.61 \mathrm{c}$ & $15.95 \mathrm{~b}$ & $11.0 \mathrm{~b}$ & $8.43 \mathrm{~b}$ & $0.49 \mathrm{c}$ \\
\hline $\mathrm{CV}(\%)$ & 15.47 & 34.10 & 12.28 & 15.01 & 17.26 \\
\hline
\end{tabular}

"Values followed by the same letter in the columns did not differ by Tukey test $(\mathrm{P}<0.05)$.

TABLE 2- Pulp firmness and soluble sugars content (SS) of 'Paluma' guava fruit as function of $\mathrm{N}$ and $\mathrm{K}_{2} \mathrm{O}$ levels. Average values of maturity stages.

\begin{tabular}{|c|c|c|}
\hline $\mathrm{N}$ and $\mathrm{K}$ rates per hectare & Pulp firmness (N) & 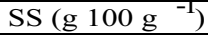 \\
\hline $67 \mathrm{~kg} \mathrm{~N}+33 \mathrm{~kg} \mathrm{~K}$ & $26.52 \mathrm{a}$ & $7.40 \mathrm{ab}$ \\
\hline $133 \mathrm{~kg} \mathrm{~N}+67 \mathrm{~kg} \mathrm{~K}$ & $29.34 \mathrm{a}$ & $6.82 \mathrm{~b}$ \\
\hline $200 \mathrm{~kg} \mathrm{~N}+100 \mathrm{~kg} \mathrm{~K}$ & $24.23 \mathrm{ab}$ & $7.78 \mathrm{a}$ \\
\hline $267 \mathrm{~kg} \mathrm{~N}+133 \mathrm{~kg} \mathrm{~K}$ & $17.24 \mathrm{~b}$ & $6.78 \mathrm{~b}$ \\
\hline CV (\%) & 34.10 & 15.01 \\
\hline
\end{tabular}

"Values followed by the same letter in the columns did not differ by Tukey test $(\mathrm{P}<0.05)$.

\section{CONCLUSIONS}

1-Higher $\mathrm{N}$ and $\mathrm{K}_{2} \mathrm{O}$ levels increased yield of the first guava growing season due to increase of fruit number. However, the fertilizer rate of $200 \mathrm{~kg} \mathrm{~N}+100 \mathrm{~kg} \mathrm{~K}_{2} \mathrm{O}$ per hectare improved fruit quality, as consequence of lower ascorbic acid degradation and of maintenance of pulp firmness.

2-The most significant changes in 'Paluma' guava fruits that occurred between the maturity stages 4 and 5 , when fruits have the appropriate characteristics for consumption, were related to soluble solids and soluble sugars accumulation.

\section{REFERENCES}

ALI, Z. M.; LAZAN, H. Guava. In: MITRA, S. Postharvest physiology and storage of tropical and subtropical fruits. Wallingford: CAB International, 1997. p. 145-165.

ALLEN, R.G.; PEREIRA, L.S.; RAES, D.; SMITH, M. Crop evapotranspiration - guidelines for computing crop water requirements. Roma: FAO Irrigation and Drainage, 1998. 300p.

AOAC. Official methods of analysis of the Association of the Agricultural Chemistis. $11^{\text {th }}$ ed. Washington: AOAC, 1992. 1115 p.

BASHIR, H. A.; ABU-GOUKH, A .A. Compositional changes during guava fruit ripening. Food Chemistry, Columbus, v. 80, n. 4, p. 557-563, 2003.

CARDOSO, E. de A.; ALVES, R. E.; MOURA, C.F. H.; ALMEIDA, A. da S.; PEREIRA, M. E. C. Frutos de goiabeira Paluma colhidos em diferentes estádios de maturação na Região do Vale do Curu, Ceará. In: CONGRESSO BRASILEIRO DE FRUTICULTURA, 17., 2002, Belém, PA. Anais.... Belém-PA: SBF, 2002. CD-ROM.

CAVALINI, F. C. Índices de maturação, ponto de colheita e padrão respiratório de goiabas 'Kumagai' ' 'Paluma'.2004. 69p. Dissertação (Mestrado em Fisiologia e Bioquímica de Plantas) - Escola Superior de Agricultura "Luiz de Queiroz", Universidade de São Paulo, Piracicaba, 2004.

CHOUdHURY, M. M.; COSTA, T. S.; ARAÚJO, J. L. P. Agronegócio da goiaba. In: CHOUDHURY, M. M. (Ed.) Goiaba. Pós-colheita. Brasília: Embrapa Informação Tecnológica, 2001. p. 9 (Frutas do Brasil, 19).

EL-BULUK, R. E.; BABIKER, E. E.; TINAY, A. H. Biochemical and physical changes in fruits of four guava cultivars during growth and development. Food Chemistry, Columbus, v. 54, n. 3, p. 279-282, 1995 .

FERREIRA, M. N. L. Distribuição radicular e consumo de água de goiabeira (Psidium guajava L.) irrigada por microaspersão 
em Petrolina-PE. 2004. 106f. Tese (Doutorado em Agronomia) Escola Superior de Agricultura "Luiz de Queiroz”, Universidade de São Paulo, Piracicaba, 2004

ESTEVES, M. T. da; CARVALHO, V. D. Modificações nos teores de amido, açúcares e grau de doçura de seis cultivares de goiabeira Psidium guajava L. em diferentes estádios de maturação. Ciência e Prática, Lavras, v. 6, n. 2, p.208-218, 1982.

GONZAGA NETO, L.; SILVA, D. J.; PEREIRA, J. R. Recomendações de calcário e fertilizantes. In: CAVALCANTI, F. J. A. (Ed.) Recomendações de adubação para o estado de Pernambuco (2 ${ }^{\mathbf{a}}$ aproximação). Recife: IPA, 1998. p. 147.

IBGE. Produção agrícola municipal: área cultivada com goiaba por grandes regiões e unidades da federação. Disponível em: $<$ http://www.ibge.gov.br>. Accesso em: 19 ago. 2005.

LIMA, M. A.; DURIGAN, J. F.; PEREIRA, F. M.; FERRAUDO, A. S. Caracterização físico-química dos frutos de 19 genótipos de goiabeira, obtidos na FCAV-UNESP. Revista Brasileira de Fruticultura. Jaboticabal. v. 21, n. 3, p. 252-257, 1999.

MALAVOLTA, E.; SOUBIHE SOBRINHO, J. Nota prévia sobre o teor de vitamina $\mathrm{C}$ em variedades brasileiras de goiaba (Psidium guajava L.). Revista de Agricultura, Piracicaba, v.26, n. 11-12, p. $397-402,1951$.

MALAVOLTA, E.; VITTI, G. C.; OLIVEIRA, S. A. de. Avaliação do estado nutricional das plantas: princípios e aplicações. Piracicaba: POTAFOS, 1989. 201 p.
MARSCHNER, H. Mineral nutrition of higher plants. $2^{\text {nd }}$ ed. London: Academic Press, 1995. 889 p

MERCADO-SILVA, E.; BENITO-BAUTISTA, P.; GARCÍAVELASCO, M. de los A. Fruit development, harvest index and ripening changes of guavas produced in central Mexico. Posthavest Biology and Technology, Amsterdam, v. 13, n. 2,p. 143-150, 1998.

NATALE, W. Diagnose da nutrição nitrogenada e potássica em duas cultivares de goiabeira (Psidium guajava L.), durante três anos. 1993. 150 f. Tese (Doutorado) - Escola Superior de Agricultura "Luiz de Queiroz", Universidade de São Paulo, Piracicaba, 1993.

PEREIRA, F. M. Rica e Paluma: novas cultivares de goiabeira. In: CONGRESSO BRASILEIRO DE FRUITICULTURA, 7., 1983, Florianópolis-SC. Anais... p.524-528.

PRADO, R. de M.; NATALE, W.; SILVA, J.A.A. da. Liming and quality of guava fruit cultivated in Brazil. Scientia Horticulturae, Amsterdam, v. 106, n. 1, p. 91-102, 2005.

TUCKER, G. A. Introduction. In: SEYMOUR, G. B.; TAYLOR, J. E.; TUCKER, G. A. Biochemistry of fruit ripening. London: Chapmal \& Hall, 1993. cap. 1, p. 2-51.

YEMN, E. W.; WILLIS, A. J. The estimation of carbohydrate in plant extracts by anthrone. The Biochemical Journal, London, v. 57, p. 504-514, 1954 